\title{
PENGARUH HYPNOBIRTHING TERHADAP INTENSITAS NYERI PADA IBU BERSALIN NORMAL DI RSUD LABUANG BAJI MAKASSAR
}

\author{
Rahmawati $^{1}$, Yusriani ${ }^{2}$, Fairus Prihatin Idris ${ }^{3}$ \\ ${ }^{1}$ Kesehatan Reproduksi, Pascasarjana Universitas Muslim Indonesia \\ ${ }^{2}$ Pascasarjana Universitas Muslim Indonesia \\ ${ }^{3}$ Pascasarjana Universitas Muslim Indonesia
}

Alamat korespondensi : (rahmareyhana@gmail.com / 085342952211$)$

\begin{abstract}
ABSTRAK
Ibu bersalin mengalami nyeri yang dapat menghambat proses persalinan. Untuk itu, diperlukan upaya untuk mengatasi nyeri. Salah satu teknik non farmakologi yang dapat menurunkan nyeri dengan menggunakan teknik hypnotherapy. Penelitian ini bertujuan mengetahui pengaruh hypnobirthing terhadap intensitas nyeri pada ibu bersalin normal di RSUD Labuang Baji Makassar. Rancangan penelitian yang dipakai dalam penelitian ini adalah penelitian eksperimental : Quasi Experimen. yaitu rancangan eksperimen dengan cara sampel diberikan kuesioner (pengukuran intensitas nyeri) sebelum dan setelah dilakukan treatment (perlakuan) yang terdiri atas dua kelompok yakni kelompok experimen dan kelompok kontrol. Pengambilan sampel dilakukan dengan metode purposive sampling dengan jumlah sampel masing-masing sebanyak 20 orang. Metode analisis data menggunakan analisis statistik dengan menggunakan Program komputer. Hasil penelitian ini didapatkan Intensitas nyeri pada ibu bersalin normal sebelum diberikan hypnobirthing rata-rata

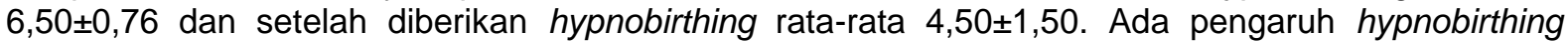
terhadap intensitas nyeri pada ibu bersalin normal di RSUD Labuang Baji Makassar $(p=0,000$ ). Kesimpulan dari penelitian menunjukkan bahwa hypnobirthing dapat menurunkan intensitas nyeri pada ibu bersalin normal. Sehingga disarankan kepada bidan untuk membantuk ibu bersalin dalam mengurangi intensitas nyeri dengan mengajarkan teknik hipnobirthing.
\end{abstract}

Kata kunci: hypnobirthing, nyeri, persalinan normal

\section{PENDAHULUAN}

Target global Milenium Development Goals (MDGs) bidang kesehatan adalah menurunkan angka kematian lbu (AKI) menjadi 102 per 100.000 kelahiran hidup. Berdasarkan Survei Demografi dan Kesehatan Indonesia (SDKI) tahun 2012, Angka Kematian Ibu (AKI) di Indonesia masih tinggi yaitu 359 per 100.000 kelahiran hidup. Angka ini sedikit menurun dibandinkan SDKI tahun 1991 masih berkisar 390 per 100.000 kelahiran hidup. Salah satu penyebab langsung kematian ibu di Indonesia adalah persalinan lama.

Salah satu yang mempengaruhi persalinan lama adalah tidak adekuatnya kontraksi uterus (his) selama kala I proses persalinan. Kala I persalinan yang lama akan menyebabkan ibu mengalami kelelahan sehingga kehabisan tenaga. Akibatnya, kontraksi uterus semakin tidak adekuat dan selanjutnya kondisi ini dapat menyebabkan kegagalan kemajuan persalinan. Kondisi lain yang mempengaruhi lama persalinan adalah kondisi psikologis meliputi persepsi ibu pada rasa nyeri dan cemas saat persalinan. Nyeri bersalin dapat menimbulkan respon fisiologis yang mengurangi kemampuan rahim saat kontraksi, sehingga bisa memperpanjang waktu persalinan.

Nyeri selama persalinan secara fisiologis disebabkan oleh dua hal, pada tahap pertama nyeri disebabkan oleh adanya dilatasi dan pendataran servik, serta adanya iskemia rahim. Nyeri tahap pertama ditransmisikan melalui segmen saraf spinalis T11-12 dan saraf-saraf asesoris torakal bawah serta saraf simpatik lumbal atas, saraf-saraf ini berasal dari korpus uteri dan servik. Nyeri yang timbul pada tahap dua disebabkan oleh adanya peregangan jaringan perineum, traksi pada peritoneum dan dorongan utero-servikal pada saat kontraksi, dan adanya kekuatan ekspulsi atau tekanan dari kandung kemih dan rektum. Impuls nyeri melalui sakrum 1-4 dan sistem parasimpatik dari jaringan perineal.

Salah satu teknik non farmakologi yang dapat menurunkan nyeri dengan menggunakan teknik hypnotherapy. Teknik seperti hipnosis telah diusulkan sebagai cara untuk membantu wanita mengatasi rasa sakit selama persalinan. Selama wanita melahirkan dapat menggunakan hipnosis dalam berbagai cara; untuk mempromosikan relaksasi, 
sebagai sarana untuk memisahkan diri dari rasa sakit atau untuk mengubah persepsinya, misalnya: memahami kontraksi sebagai cara untuk lebih dekat dengan melahirkan bayinya.

Hypnotherapy dalam persalinan atau dikenal dengan hypnobirthing dilakukan dengan cara hipnosis yakni perubahan status kesadaran saat konsentrasi individu terfokus dan distraksi minimal, hipnosis juga bisa digunakan untuk mengendalikan nyeri, bahwa hipnosis dapat mencegah stimulus nyeri dalam otak menembus pikiran sadar, teori tertentu menyebutkan bahwa hipnosis bekerja dengan mengaktifkan saraf dalam otak yang menyebabkan pelepasan zat seperti morfin alamiah yang disebut enkefalin dan endorphin. Stimulus hypnobirthing merangsang pituitary mengeluarkan Pro-opiomelanocortin (POMC) sehingga dapat meningkatkan sekresi beta endorfin. Pengeluaran beta endorfin meningkatkan toleransi ibu terhadap nyeri.

Penelitian yang dilakukan di RSUD Wangaya ditemukan bahwa tingkat nyeri pada ibu dengan persalinan normal di RSUD Wangaya sebelum diberikan hypnotherapy, $100 \%$ mengalami nyeri berat dan sesudah diberikan hypnotherapy 63,3\% mengalami nyeri sedang, 36,7\% mengalami nyeri berat, hasil analisis data menggunakan uji statistik Paired T-Test diperoleh nilai $\mathrm{p}$ didapatkan sebesar 0,001 dengan taraf signifikansi 0,05, hal ini menunjukan bahwa $p<0,05$ sehingga dapat disimpulkan ada pengaruh yang signifikan hypnotherapy terhadap nyeri pada persalinan normal di RSUD Wangaya Kota Denpasar.

Pada data Rumah Sakit Umum Daerah Labuang Baji Makassar tahun 2015 diproleh data ibu bersalin yang melahirkan periode Januari - Desember sebanyak 683 orang dengan rata-rata 100 orang perbulan. Pada tahun 2016 meningkat menjadi 700 ibu yang melakukan bersalinan. Hasil wawancara yang peneliti lakukan, 10 ibu mengatakan ibu sulit berkonsentrasi terhadap persalinan akibat nyeri yang timbul, merasakan sesak dan kesulitan untuk mengatur nafas, juga mengatakan trauma terhadap persalinannya. Sejauh ini belum menjadi kebijakan rumah sakit untuk menerakpan teknik non farmakologi hypnobirthing untuk menurunkan intensitas nyeri pada ibu bersalin di Rumah Sakit Umum Daerah Labuang Baji Makassar walaupun bererapa bidan telah mengikuti pelatihan hypnobirthing dan telah mendapatkan sertifikat. Oleh karena itu, peneliti tertarik untuk meneliti lebih lanjut mengenai pengaruh hypnobirthing terhadap intensitas nyeri pada ibu bersalin normal di RSUD Labuang Baji Makassar

\section{BAHAN DAN METODE}

\section{Lokasi, Populasi, Sampel}

Penelitian ini dilaksanakan di RSUD Labuang Baji Makassar pada bulan Agustus September 2018. Populasi dalam penelitian ini adalah ibu bersalin yang melahirkan normal di RSUD Labuang Baji Makassar tahun 2018 dengan rata-rata perbulan sebanyak 57 orang dengan jumlah sampel pada penelitian ini adalah 40 orang yang terdiri dari eksperimen 20 orang dan kontrol 20 orang.

1. Kriteria inklusi:
a. Ibu yang bersalin normal.
b. Kesadaran umum baik.
c. Bersedia menjadi responden

2. Kkriteria eksklusi:
a. Ibu dengan penyulit persalinan.
b. Kesadaran umum jelek.
c. Tidak bersedia menjadi responden

\section{Pengumpulan Data}

1. Data sekunder adalah yang diperoleh dari pihak lain dalam hal ini data awal mengenai persalinan di Rumah Sakit Umum Daerah Labuang Baji Makassar.

2. Data primer adalah data yang diperoleh sendiri oleh peneliti dari hasil pengukuran atau pengamatan.

\section{Pengolahan Data}

1. Editing

Editing adalah tahapan kegiatan memeriksa validitas data yang masuk.

2. Coding

Coding adalah tahapan kegiatan mengklasifikasi data dan jawaban menurut kategori masing-masing sehingga memudahkan dalam pengelompokan data.

3. Processing

Processing adalah tahapan kegiatan memproses data agar dapat dianalisis. Pemrosesan data dilakukan dengan cara memasukkan data hasil pengisian kuesioner ke dalam master tabel.

4. Cleaning

Cleaning yaitu tahapan kegiatan pengecekan kembali data yang sudah di masukkandan melakukan koreksi bila terdapat kesalahan. (Lapau, 2013).

\section{Analisis Data}

1. Analisis Univariat

Analisis univariat dilakukan dari tiap variabel dari hasil penelitian berupa distribusi frekuensi dan presentase dari tiap variabel.

2. Analisis Bivariat

Analisis bivariat merupakan analisis untuk mengetahui intraksi dua variabel atau hubungan antara variabel independen 
dan variabel dependen, dengan menggunakan data ordinal. Terlebih dahulu dilakukan uji normalitas data menggunakan uji kolmogorov-smirnov, apabila data terdistribusi normal dilanjutkan dengan independen sample t-test. Bila data tidak terdistribusi normal maka menggunakan uji mann whitney dengan taraf signifikan (a) $0,05 \%$ atau tingkat kepercayaan $95 \%$.

\section{HASIL PENELITIAN}

1. Analisis Univariat

Tabel 1 Distribusi Karakteristik Ibu Bersalin Normal di Rumah Sakit Umum Daerah (RSUD) Labuang Baji Makassar.

\begin{tabular}{|c|c|c|c|c|c|c|}
\hline \multirow{3}{*}{ Karakteristik } & \multicolumn{4}{|c|}{ Kelompok } & \multirow{2}{*}{\multicolumn{2}{|c|}{ Total }} \\
\hline & \multicolumn{2}{|c|}{$\begin{array}{l}\text { Hipno } \\
\text { birthing }\end{array}$} & \multicolumn{2}{|c|}{ Kontrol } & & \\
\hline & \begin{tabular}{|c|}
$\mathrm{n}$ \\
$(20)$
\end{tabular} & $\begin{array}{c}\% \\
(100)\end{array}$ & $\begin{array}{c}n \\
(20)\end{array}$ & $\begin{array}{c}\% \\
(100)\end{array}$ & $\begin{array}{c}\mathrm{n} \\
(20)\end{array}$ & $\begin{array}{c}\% \\
(100)\end{array}$ \\
\hline $\begin{array}{c}\text { Umur } \\
<25 \text { Tahun }\end{array}$ & 9 & 45,0 & 7 & 35,0 & 16 & 40,0 \\
\hline 25-35 Tahun & 4 & 20,0 & 9 & 45,0 & 13 & 32,5 \\
\hline$>35$ Tahun & 7 & 35,0 & 4 & 20,0 & 11 & 27,5 \\
\hline Pendidikan & & & & & & \\
\hline $\mathrm{SD}$ & 1 & 5,0 & 0 & 0,0 & 1 & 2,5 \\
\hline SMP & 9 & 45,0 & 4 & 20,0 & 13 & 32,5 \\
\hline SMA & 9 & 45,0 & 16 & 80,0 & 25 & 62,5 \\
\hline $\begin{array}{l}\text { Perguruan } \\
\text { Tinggi }\end{array}$ & 1 & 5,0 & 0 & 0,0 & 1 & 25 \\
\hline Gravid & & & & & & \\
\hline $1-2$ & 15 & 75,0 & 11 & 55,0 & 26 & 65,0 \\
\hline$\geq 3$ & 5 & 25,0 & 9 & 45,0 & 14 & 35,0 \\
\hline Partus & & & & & & \\
\hline 0 & 9 & 45,0 & 10 & 50,0 & 19 & 47,5 \\
\hline $1-2$ & 9 & 45,0 & 7 & 35,0 & 16 & 40,0 \\
\hline$\geq 3$ & 2 & 10,0 & 3 & 15,0 & 5 & 12,5 \\
\hline Abortus & & & & & & \\
\hline 0 & 19 & 95,0 & 19 & 95,0 & 38 & 95,0 \\
\hline$\geq 1$ & 1 & 5,0 & 1 & 5,0 & 2 & 5,0 \\
\hline $\begin{array}{l}\text { Jenis Kelamin } \\
\text { Anak }\end{array}$ & & & & & & \\
\hline Laki-laki & 9 & 45,0 & 10 & 50,0 & 19 & 47,5 \\
\hline Perempuan & 11 & 55,0 & 10 & 50,0 & 21 & 52,5 \\
\hline
\end{tabular}

Tabel 1 menunjukkan bahwa sebagian besar responden berusia $<25$ tahun yakni sebanyak 16 responden $(40,0 \%)$, sebagian besar responden pendidikannya SMA yakni sebanyak 25 responden $(62,5 \%)$, sebagian besar responden jumlah kehamilannya 1-2 yakni sebanyak 26 responden $(65,0 \%)$, sebagian besar responden partusnya 0 yakni sebanyak 19 responden (47,5\%), dan sebagian besar responden anaknya perempuan yakni sebanyak 21 responden $(52,5 \%)$

Tabel 2 Distribusi Berdasarkan Intensitas Nyeri Pada Ibu Bersalin Normal di Rumah Sakit Umum Daerah (RSUD) Labuang Baji

\begin{tabular}{|c|c|c|c|c|c|c|}
\hline \multirow{4}{*}{$\begin{array}{l}\text { Intensitas } \\
\text { Nyeri }\end{array}$} & \multirow{2}{*}{\multicolumn{4}{|c|}{ Kelompok }} & \multirow{3}{*}{\multicolumn{2}{|c|}{ Total }} \\
\hline & & & & & & \\
\hline & \multicolumn{2}{|c|}{$\begin{array}{c}\text { Hipno } \\
\text { birthing }\end{array}$} & \multicolumn{2}{|c|}{ Kontrol } & & \\
\hline & $\begin{array}{c}n \\
(20) \\
\end{array}$ & $\begin{array}{c}\% \\
(100) \\
\end{array}$ & \begin{tabular}{|c|}
$n$ \\
$(20)$ \\
\end{tabular} & $\begin{array}{c}\% \\
(100)\end{array}$ & $\begin{array}{c}\mathrm{n} \\
(20) \\
\end{array}$ & $\begin{array}{c}\% \% \\
(100) \\
\end{array}$ \\
\hline & & & & & & \\
\hline & 0 & & 0 & 0 & 0 & \\
\hline & 7 & 35,0 & 10 & 50,0 & 17 & 42,5 \\
\hline $\begin{array}{l}\text { Nyeri } \\
\text { Berat }\end{array}$ & 13 & 65,0 & 10 & 50,0 & 23 & 57,5 \\
\hline $\begin{array}{l}\text { Post Test } \\
\text { Nyeri }\end{array}$ & & & & & & \\
\hline $\begin{array}{l}\text { Ring } \\
\text { Nyer }\end{array}$ & 8 & 40,0 & 0 & 0,0 & 8 & 20,0 \\
\hline $\begin{array}{l}\text { Sedang } \\
\text { Nyeri }\end{array}$ & 12 & 60,0 & 11 & 55,0 & 23 & 57,5 \\
\hline Berat & 0 & 0,0 & 9 & 45,0 & 9 & 22,5 \\
\hline
\end{tabular}

Tabel 2 menunjukkan bahwa pada saat pre test sebagian besar mengalami nyeri berat baik itu pada kelompok hipnobirthing $(65,0 \%)$ maupun kelompok kontrol $(50 \%)$. Adapun pada saat post test didapatkan pada kelompok hypnobirthing ibu intensitas nyerinya ringan $(40,0 \%)$ dan nyeri berat $(0 \%)$ sedangkan kelompok kontrol didapatkan intensitas nyeri ringan $(0 \%)$ dan nyeri berat $(45 \%)$.

2. Analisis Bivariat

Tabel 3 Pengaruh hypnobirthing terhadap intensitas nyeri pada ibu bersalin normal di RSUD Labuang Baji Makassar

\begin{tabular}{|c|c|c|c|c|}
\hline \multirow{2}{*}{ Kelompok } & \multirow{2}{*}{$n$} & \multicolumn{2}{|c|}{$\begin{array}{c}\text { Intensitas Nyeri } \\
(\text { Mean } \pm S D)\end{array}$} & \multirow{2}{*}{$\begin{array}{c}P \\
\text { value }\end{array}$} \\
\hline & & Hasil & Perbedaan & \\
\hline 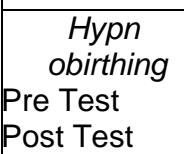 & $\begin{array}{l}20 \\
20\end{array}$ & $\begin{array}{l}6,50 \pm 0,76 \\
4,50 \pm 1,50\end{array}$ & $2,00 \pm 1,25$ & $0,000^{*}$ \\
\hline $\begin{array}{l}\text { Kontrol } \\
\text { Pre Test } \\
\text { Post Test }\end{array}$ & $\begin{array}{l}20 \\
20\end{array}$ & $\begin{array}{l}5,95 \pm 1,09 \\
6,15 \pm 1,22\end{array}$ & $0,20 \pm 0,52$ & $0,102^{*}$ \\
\hline \begin{tabular}{|l}
\multicolumn{1}{|}{ Perubahan } \\
Nyeri \\
Hypno \\
birthing \\
Kontrol
\end{tabular} & $\begin{array}{l}20 \\
20\end{array}$ & $\begin{array}{l}2,00 \pm 125 \\
-0,20 \pm 0,52\end{array}$ & $2,20 \pm 0,30$ & $0,000^{* *}$ \\
\hline
\end{tabular}

Tabel 3 menunjukkan bahwa dari 20 responden, perubahan intensitas nyeri pada kelompok hypnobirthing rata-rata $2,00 \pm 1,25$ dan pada kelompok kontrol ratarata $-0,20 \pm 0,52$, dengan perbedaan ratarata $4,25 \pm 1,61$. Berdasarkan uji statistik Wilcoxon diperoleh nilai $\mathrm{p}=0,000$, hal ini berarti nilai $p<\alpha(0,05)$. Hal ini berarti ada perbedaan intensitas nyeri sebelum dan setelah dilakukan hypnobirthing pada ibu 
bersalin normal di RSUD Labuang Baji Makassar, sedangkan pada kelompok kontrol didapatkan tidak ada perbedaan intensitas nyeri pre dan post test $(p=0,102)$. Adapun uji statistik Mann Whitney terhadap perubahan intensitas nyeri diperoleh nilai $p=0,000$, hal ini berarti nilai $p<\alpha(0,05)$. Hal ini berarti ada pengaruh hypnobirthing terhadap intensitas nyeri pada ibu bersalin normal di RSUD Labuang Baji Makassar.

\section{PEMBAHASAN}

1. Intensitas nyeri pada ibu bersalin normal Nyeri bersalin dapat menimbulkan respon fisiologis yang mengurangi kemampuan rahim saat kontraksi, sehingga bisa memperpanjang waktu persalinan (Bobak, Lowdermilk, \& Jensen, 2015). Dari beberapa kasus, kelahiran bukan peristiwa membahagiakan tetapi menjadi suatu masa penuh rasa nyeri, rasa takut, penderitaan bahkan kematian. Nyeri adalah pengalaman sensori atau emosional tidak menyenangkan akibat kerusakan jaringan potensial atau aktual (Judha, 2012).

Nyeri selama persalinan secara fisiologis disebabkan oleh dua hal, pada tahap pertama nyeri disebabkan oleh adanya dilatasi dan pendataran serviks, serta adanya iskemia rahim. Nyeri tahap pertama ditransmisikan melalui segmen saraf spinalis T11-12 dan saraf - saraf asesoris torakal bawah serta saraf simpatik lumbal atas, saraf - saraf ini berasal dari korpus uteri dan serviks. Nyeri yang timbul pada tahap dua disebabkan oleh adanya peregangan jaringan perineum, traksi pada peritoneum dan dorongan utero-servikal pada saat kontraksi, dan adanya kekuatan ekspulsi atau tekanan dari kandung kemih dan rektum. Impuls nyeri melalui sakrum 14 dan sistem parasimpatik dari jaringan perineal (Bobak, Lowdermilk, \& Jensen, 2015).

Pada penelitian ini intensitas nyeri antara satu responden dengan responden yang lain bervariasi. Hal ini disebabkan karena nyeri dipengaruhi oleh berbagai faktor seperti umur dan pendidikan. Dalam penelitian ini responden yang mengalami nyeri berat lebih banyak yang berusia $<25$ tahun $(45 \%)$ dibandingkan yang berusia > 35 tahun (35\%). Hal ini disebabkan karena usia muda seseorang belum memiliki pengalaman yang cukup terkait persalinan dan nyeri sehingga mempersepsikan nyeri lebih berat dibanding yang berusia lebih tua selain itu umur ibu yang lebih muda memiliki sensori nyeri yang lebih intens dibanding dengan ibu yang memiliki umur yang lebih tua. Umur muda cenderung dikaitkan dengan kondisi psikologis yang masih labil yang memicu terjadinya ketakutan dan kecemasan sehingga nyeri yang dirasakan semakin lebih kuat. Umur juga dipakai sebagai salah satu faktor dalam menentukan toleransi terhadap nyeri. Pada paritas ibu yang primipara intensitas kontraksi uterus lebih kuat dibandingkan pada ibu yang multipara dan ibu multipara memiliki pengalaman persalinan sebelumnya akan lebih mudah beradaptasi dengan nyeri dibandingkan dengan ibu yang belum pernah memiliki pengalaman dalam hal ini ibu primipara (Umboh, 2015).

Selain itu dalam penelitian ini, ibu yang pendidikannya SMP dan SMA (45\%) lebih banyak yang mengalami nyeri. Hal ini menunjukkan bahwa yang mengalami nyeri lebih banyak adalah ibu bersalin yang memiliki pendidikan rendah yang menurut asumsi peneliti pengetahuan tentang manajemen nyeri dan cara penatalaksanaan nyeri bisa didapatkan melalui pendidikan baik formal maupun non formal.

Menurut Yatim (2001) mengatakan bahwa pendidikan mempengaruhi ibu bersalin dalam menghadapi nyeri saat persalinan, hal ini dikaitkan dengan kemampuan mendapatkan informasi. Menurut Koentjoroningrat (1997, dalam Nursalam, 2001), makin tinggi tingkat pendidikan seseorang, makin mudah orang tersebut menerima informasi sehingga makin banyak pula pengetahuan yang dimiliki terutama yang berkaitan dengan nyeri saat persalinan. Sebaliknya, pendidikan yang rendah akan menghambat seseorang dalam menerima informasi sehingga mengakibatkan berkurangnya informasi tentang nyeri saat persalinan sedangkan menurut Notoatmojo (2007) mengatakan bahwa tingkat pengetahuan sangat dipengaruhi oleh latar belakang pendidikan, semakin tinggi tingkat pendidikan seseorang semakin mudah menerima informasi sehingga semakin banyak pula pengetahuan yang dimiliki dan begitu juga sebaliknya. Pengetahuan merupakan domain yang sangat penting untuk terbentuknya tindakan seseorang. Pengetahuan merupakan hal yang penting bagi setiap individu karena dengan modal pengetahuan, seseorang bisa bersikap melakukan suatu usaha termasuk melakukan tindakan yang bisa menyebabkan nyeri berkurang. Hal ini juga 
sejalan dengan teori WHO bahwa pendidikan sangat menentukan untuk mengembangkan diri dan meningkatkan kematangan intelektual seseorang dimana kematangan intelektual akan mempengaruhi wawasan dan cara berfikir seseorang untuk mengambil keputusan sehingga diharapkan makin tinggi tingkat pendidikan seseorang makin baik perilakunya dalam menghadapi proses persalinan.

2. Pengaruh hypnobirthing terhadap intensitas nyeri pada ibu bersalin normal di RSUD Labuang Baji Makassar

Hasil dari penelitian ini berdasarkan uji statistik Mann Whitney didapatkan ada pengaruh hypnobirthing terhadap intensitas nyeri pada ibu bersalin normal di RSUD Labuang Baji Makassar $(p=0,000)$, dimana hypnobirthing dapat menurunkan intensitas nyeri pada ibu bersalin normal.

Nyeri adalah suatu sensori yang tidak menyenangkan dari satu pengalaman emosional yang disertai kerusakan jaringan secara aktual/potensial (Medical Surginal Nursing), nyeri merupakan suatu perasaan yang tidak menyenangkan dan disebabkan oleh stimulus spesifik mekanis, kimia, elektrik pada ujung - ujung syaraf serta tidak dapat diserah terimakan kepada orang lain (Kusuma, et al, 2009).

Bagian otak yang terlibat dalam sensasi nyeri adalah talamus, hipotalamus, formasio retikularis, sistem limbik dan korteks serebri (Mander, 2004). Cingulated gyrus anterior (depan) merupakan salah satu tempat-tempat di dalam otak yang dimodulasi atau diatur selama analgesia yang ditimbulkan oleh hipnosis. Penekanan aktivitas saraf, korteks sensori dan sistem amygdalalimbig tampaknya menghambat penafsiran emosional tentang sensasi sensasi seperti nyeri (Cyna et al, 2006).

Ketika persepsi nyeri sudah berubah menjadi rasa nyaman maka individu akan merasa aman. Apabila individu berada di lingkungan yang aman, saraf vagus tidak bermielin bekerja aktif. Vagus tidak bermielin menghantarkan sinyal saraf lebih lambat dibanding vagus bermielin, sehingga otak mempunyai kesempatan untuk melakukan kompensasi terhadap nyeri. Saat saraf otonom mengaktivasi saraf tidak bermielin tubuh akan merespon dengan immobilisation without fear. Dalam keadaan immobilisasi tubuh akan meningkatkan ambang batas nyeri sehingga akan mempengaruhi intensitas nyeri (Porges, 2012).
Salah satu penyebab dari nyeri adalah iskemia otot uteri yaitu penurunan aliran darah sehingga oksigen lokal mengalami deficit akibat kontraksi arteri mometrium. Hipnosis bekerja dengan baik dengan amigdala dan hipotalamus, untuk mengubah respon stres. Hipnosis memungkinkan konsentrasi terfokus dan relaksasi, sehingga terjadi peningkatan oksigen ke seluruh sel-sel tubuh. Peningkatan oksigen memiliki pengaruh besar pada penurunan respon otonom pasien terhadap stres. Mengisi sel dengan oksigen melalui hipnosis mengurangi rasa nyeri seperti peregangan sel otot meningkatkan aliran darah (yaitu oksigen) dan mengurangi rasa nyeri (Jensen \& Mark, 2011).

Hypnobirthing ini tidak memiliki potensi efek samping terhadap bayi, mampu menghadirkan rasa nyaman, rileks, dan aman menjelang kelahiran, membuat ibu mampu mengontrol sensasi rasa nyeri pada saat kontraksi uterus, persiapan hypnobirthing bermanfaat bagi semua keluarga, termasuk mereka yang karena memang mengalami suatu keadaan khusus, berada dalam kategori resiko tinggi jika persalinan mereka berlangsung tidak seperti yang diharapkan (Brown \& Hammond, 2007). Temuan - temuan yang signifikan dari percobaan klinis tentang pendekatan-pendekatan hipnotis untuk penanggulangan rasa nyeri, dan menyatakan bahwa hipnosis lebih efektif daripada pengobatan placebo (Jensen \& Patterson, 2014).

Menurut Andriana (2007) salah satu manfaat hypnobirthing adalah meminimalkan bahkan menghilangkan rasa takut, ketegangan, bahkan sindrom rasa sakit dan kepanikan selama proses persalinan dan periode setelahnya sehingga tidak menjadi trauma. Hipnosis diri atau self hypnosis adalah suatu proses sederhana agar diri kita berada dalam kondisi rileks, tenang dan terfokus guna mencapai suatu hasil atau tujuan tertentu. Hipnosis diri juga dapat dikategorikan sebagai meditasi karena baik meditasi maupun hypnosis diri sama - sama menempatkan diri dan pikiran kita dalam kondisi rileks, tenang dan terfokus (Andriana, 2007).

Salah satu teknik non farmakologi yang dapat menurunkan nyeri dengan menggunakan teknik hypnotherapy. Teknik seperti hipnosis telah diusulkan sebagai cara untuk membantu wanita mengatasi rasa sakit selama persalinan. Selama 
wanita melahirkan dapat menggunakan hipnosis dalam berbagai cara; untuk mempromosikan relaksasi, sebagai sarana untuk memisahkan diri dari rasa sakit atau untuk mengubah persepsinya, misalnya: memahami kontraksi sebagai cara untuk lebih dekat dengan melahirkan bayinya (Madden, Middleton, Cyna, Matthewson, \& Jones, 2016).

Hypnotherapy dalam persalinan atau dikenal dengan hypnobirthing dilakukan dengan cara hipnosis yakni perubahan status kesadaran saat konsentrasi individu terfokus dan distraksi minimal, hipnosis juga bisa digunakan untuk mengendalikan nyeri, bahwa hipnosis dapat mencegah stimulus nyeri dalam otak menembus pikiran sadar, teori tertentu menyebutkan bahwa hipnosis bekerja dengan mengaktifkan saraf dalam otak yang menyebabkan pelepasan zat seperti morfin alamiah yang disebut enkefalin dan endorphin (Kozier, 2010). Stimulus hypnobirthing merangsang pituitary mengeluarkan Pro-opiomelanocortin (POMC) sehingga dapat meningkatkan sekresi beta endorfin. Pengeluaran beta endorfin meningkatkan toleransi ibu terhadap nyeri (Nursalam, Pradanie, \& Trisnadewi, 2008).

Hypnobirthing merupakan kombinasi praktik hypnosis terhadap diri sendiri / autohypnosis (self Hypnosis) dengan panduan dari hypnotherapis untuk mencapai relaksasi mendalam. Hypnobirthing dapat digunakan untuk menghadapi dan menjalani kehamilan serta persiapan melahirkan dengan cara alami, tenang, dan nyaman serta kesehatan jiwa janin (Semple \& Newburn, 2011); (Kuswandi, 2011). Hypnobirthing memiliki beberapa manfaat di antaranya mengurangi rasa nyeri, meningkatkan kejadian persalinan spontan, mengurangi resiko operasi, mempercepat pemulihan ibu post partum, membantu suplay oksigen kepada bayi selama proses persalinan sehingga bayi yang lahir memiliki nilai APGAR yang lebih baik (Bobak, Lowdermilk, \& Jensen, 2015).

Penelitian yang dilakukan di RSUD Wangaya ditemukan bahwa tingkat nyeri pada ibu dengan persalinan normal di RSUD Wangaya sebelum diberikan hypnotherapy, $100 \%$ mengalami nyeri berat dan sesudah diberikan hypnotherapy $63,3 \%$ mengalami nyeri sedang, 36,7\% mengalami nyeri berat, hasil analisis data menggunakan uji statistik Paired T-Test diperoleh nilai $p$ didapatkan sebesar 0,001 dengan taraf signifikansi 0,05 , hal ini menunjukan bahwa $p<0,05$ sehingga dapat disimpulkan ada pengaruh yang signifikan hypnotherapy terhadap nyeri pada persalinan normal di RSUD Wangaya Kota Denpasar (Agustini, Pradnya, \& Risnayanti, 2016). Penelitian yang dilakukan oleh (Nursalam, Pradanie, \& Trisnadewi, 2008) menemukan bahwa metode relaksasi hypnobirthing terbukti meningkatkan toleransi nyeri dan menurunkan respons kecemasan pada ibu inpartu kala I fase aktif ( $p=0.015)$.

Penelitian yang dilakukan oleh (Imannura, Budhiastuti, \& Poncorini, 2016) didapatkan setelah intervensi, ibu hamil yang menerima hypnobirthing memiliki nyeri terendah $41,33(p=0,003)$. Ibu hamil yang tidak menerima hypnobirthing memiliki tingkat nyeri serendah 51,60 ( $\mathrm{p}=$ 0,003 ) dan ada perbedaan penurunan nyeri antara kedua kelompok secara statistik signifikan.

Penelitian yang lain menunjukkan bahwa wanita yang menggunakan hipnosis menilai nyeri persalinan mereka kurang berat dibandingkan dengan kontrol ( $P$ $<0,01)$. Yang lain menunjukkan bahwa hipnosis mengurangi opioid (meperidine) persyaratan $(P<0,001)$, dan meningkatkan kejadian tidak memerlukan analgesia farmakologis dalam persalinan $(P<0,001)$. (Cyna, McAuliffe, \& Andrew, 2004).

Adapun penelitian selanjutnya didapatkan wanita yang menggunakan teknik hipnosis untuk persalinan di rumah sakit mungkin menghadapi hambatan yang terkait dengan resistensi pemberi pelayanan atau kebijakan kelembagaan. Efek ansiolitik dan analgesik potensial dari hipnosis klinis untuk persalinan patut dipelajari lebih lanjut. Perawat yang merawat wanita selama persalinan dan melahirkan dapat meningkatkan pengetahuan dan keterampilan mereka dengan strategi untuk mendukung teknik hipnoterapeutik (Beebe, 2014).

Adapun penelitian yang dilakukan oleh (Triyani, Fatimah, \& Aisyah, 2016) ditemukan bahwa hipnosis berpengaruh dalam menurunkan tingkat kecemasan ibu nullipara di triwulan III ( $p$ value $<0,001$ ). Sedangkan penelitian lainnya menemukan bahwa hypnobirthing berpengaruh terhadap penurunan tingkat kecemasan, tekanan darah dan denyut nadi pada ibu primigravida trimester III (Marliana, Kuntjoro, \& Wahyuni, 2016).Selain itu, penelitian di Australia ditemukan bahwa lama kala II pada ibu yang dilakukan 
hypnobirthing rata-rata lebih singkat dibandingkan yang tidak dilakukan hypnobirthing $51 \%$ tidak menggunakan obat rasa sakit sama sekali dan tingkat ketidaknyamanan keseluruhan untuk persalinan dan kelahiran adalah 5,8 dari 10 dengan $32 \%$ skala nyerinya di bawah 5,8 , termasuk dua peserta yang mencatat ketidaknyamanan nol (Phillips-Moore, 2012).

\section{KESIMPULAN}

1. Intensitas nyeri pada ibu bersalin normal di RSUD Labuang Baji Makassar sebelum diberikan hypnobirthing nyeri berat $65 \%$
2. Intensitas nyeri pada ibu bersalin normal di RSUD Labuang Baji Makassar setelah diberikan hypnobirthing nyeri sedang $60 \%$

3. Ada pengaruh hypnobirthing terhadap intensitas nyeri pada ibu bersalin normal di RSUD Labuang Baji Makassar

\section{SARAN}

1. Diharapakan ibu bersalin untuk melakukan upaya untuk mengurangi nyeri selama proses persalinan dengan menerapkan teknik relaksasi dan hipnobirthing.

2. Diharapkan kepada bidan untuk membantuk ibu bersalin dalam mengurangi intensitas nyeri dengan mengajarkan teknik hipnobirthing.

\section{DAFTAR PUSTAKA}

Agustini, I. G., Pradnya, I. M., \& Risnayanti, N. P. (2016). Pengaruh yang signifikan hypnotherapy terhadap nyeri pada persalinan normal di RSUD Wangaya Kota Denpasar. Jurnal Dunia Kesehatan , 5(2):67-71.

Bobak, I., Lowdermilk, D., \& Jensen, M. (2015). Buku Ajar Keperawatan Maternitas. Jakarta: EGC.

Judha, M. (2012). Teori Pengukuran Nyeri dan Nyeri Persalinan. Yogyakarta: Nuha Medika.

Kemenkes RI. (2014). Situasi Kesehatan Ibu. Jakarta: Pusat Data dan Informasi Kementerian Kesehatan RI.

Kozier, B. (2010). Buku Ajar Fonddamental Keperawatan. Jakarta: EGC.

Kusuma, T. E. (2013). Bebas Hipertensi dengan Self Hypnosis. Jakarta: Noura Books (Mizan Grup).

Madden, K., Middleton, P., Cyna, A. M., Matthewson, M., \& Jones, L. (2016). Hypnosis for pain management during labour and childbirth. Cochrane Database of Systematic Reviews, Issue 5. Art. No.: CD009356.DOI: 10.1002/14651858.CD009356.pub3.

Nursalam, Pradanie, R., \& Trisnadewi, I. A. (2008). Pengaruh metode relaksasi hypnobirthing terhadap toleransi nyeri dan respons kecemasan pada ibu inpartu kala I fase aktif. Jurnal Ners, Vol.3 No.1 April 2008 : 54 60 .

Triyani, S., Fatimah, \& Aisyah. (2016). Pengaruh Hypnosis Terhadap Tingkat Kecemasan lbu Hamil Nullipara triwulan 3 pada masa persiapan menghadapi persalinan di Puskesmas Kecamatan Cengkareng Jakarta Barat. The Southeast Asian Journal of Midwifery, Vol. 2, No.1, Oktober 2016, Hal: 24 - 3 